\title{
High Burden of Antibiotic-Resistant Bacteria from Wastewater in Ethiopia: A Systematic Review
}

This article was published in the following Dove Press journal:

Risk Management and Healthcare Policy

\section{Tsegahun Asfaw \\ Deribew Genetu \\ Demissew Shenkute}

Department of Medical Laboratory Science, Debre Berhan University, Debre Birhan, North Shwa, Ethiopia
Correspondence: Tsegahun Asfaw

P. Box: 445

Email tsegahun.asfaw12@gmail.com
Background: Currently, antibiotic-resistant bacteria (ARB) have become a serious global problem and considered as One Health challenge. Despite, wastewater contains a wide range of microbial pathogens and plays a significant role in the dissemination of ARB in the environment. However, it is the most overlooked in developing countries, particularly in Ethiopia.

Methods: Different article searching devices like PubMed, Web of Science, Scopus, and Google Scholar were used to select research article by using the key terms. Hand search using a reference list is also used to retrieve the article. Preferred reporting items for systematic review and meta-analysis (PRISMA) guideline was used for literature search strategy, selection of publications, data extractions, and reporting result for the review process.

Results: A total of seven original research articles were included from a total of 35,999 research articles obtained from the different searching techniques. The selected articles were used, the same study design and laboratory methods to isolate different types of resistant bacteria. All studies isolate pathogenic bacteria and highlighted the presence of resistant bacteria for multiple antibiotics.

Conclusion: Multidrug resistance (MDR) bacteria were isolated from wastewater. This is an indication for the possible presence of pathogenic organisms that are discharged into the receiving environment probably waterbodies (lake and revers) posing risk to public health, animal, and environment. In Ethiopia the coverage of safe water supply is poor. This obligated the society to use untreated water from rivers, lakes and others. The outlet of most urban sewage from hospital, hotels, and industries are directly running to those water bodies due to lack of proper wastewater management system. Therefore ARB is a direct threat to those people that use those water bodies.

Keywords: antibiotic resistance, antibiotic-resistant bacteria, wastewater, Ethiopia

\section{Introduction}

During the last century, detection of microorganisms as causes of infections and findings of antibiotics as effective therapeutic agents have promoted to safeguard the wellbeing of the people and animals. ${ }^{1}$ Despite the innovation of many antibiotics, the emergence of antibiotic-resistant bacterial (ARB) strains becomes the highest global public health agenda. Tackling the spread and emergence of antibiotic resistance are a high priority for the World Health Organization (WHO). Antimicrobial Resistance (AMR) is a global threat to the effectiveness of antimicrobials, challenging their value for both the prevention and treatment of infections. ${ }^{2}$ Antimicrobial resistance is a result of complex interacting factors or resistance network; ${ }^{3}$ that links clinical factors (animal and human health) and 
environmental factors (antimicrobial drug and AMR organism in the soil and waterbodies). ${ }^{4}$ Aside from unselective use of antibiotics in human medicine, farming and agriculture, inappropriate wastewater disposal disrupts the microbial balance in favor of resistant bacteria by selective pressure. ${ }^{5}$ Different literature across the world indicates that wastewater is the potential source of resistant pathogens. Wastewater contains some contaminants that result from the mixing of various sources, discharged by domestic residences, commercial properties, industry, agriculture, pharmaceuticals, and hospitals. ${ }^{6}$ The presence of ARB and ARGs within the environment is selected for and enriched by antibiotics found in sewage and agriculture runoff results from indiscriminate and increased use. ${ }^{5,6}$ Wastewater constitutes a way of dissemination of ARB and ARG among human and animal populations and introduced in natural bacterial ecosystems, ${ }^{7}$ where nonpathogenic bacteria serve as a reservoir of resistance gene. ${ }^{8}$ Moreover, if the resistant genes are transmissible, it causes the wide distribution of ARB and their genes. Infections caused by ARB are usually difficult to treat, prolong hospitalization, and increase the cost of treatment. ${ }^{9}$ These conditions become major public health problems especially in developing country including Ethiopia. To limit its public health impact critical evaluation, treatment and periodic assessment of wastewater released to the receiving environment is mandatory. Therefore, this study aims to review research from Ethiopia, done on the resistance pattern of bacteria isolated from wastewater and the environment. The finding obtained from this study is hoped to provide baseline data for policymakers, healthcare workers and local authorities so that these responsible bodies would recognize the need for a wastewater management system, and proper antibiotic usage.

\section{Study Methods Research Question}

This literature review was guided by the questions "What is the burden of antibiotic resistance pathogens in wastewater released to the environment?"

\section{Data Source and Searching Strategies}

The First search was done on June 21, 2020, in PubMed, Web of Science, Embase, Scopus, Directory of Open Access Journal (DOAJ), and Google Scholars. Hand search using a reference list is also used to retrieve the article. The key terms "Antimicrobial-Resistance", OR "Drug-Resistance" AND "Bacteria" OR "Pathogens" AND "Wastewater" OR "Sewage" were used.

\section{Selection and Eligibility Criteria}

A stepwise relevance selection/screening was done. First, all articles not done in Ethiopia are removed. Then, titles and abstracts were considered for screening and to remove duplication. All article seems relevant went through of thefull text article observation and review. Studies were eligible for inclusions if they were original article which addresses ARB in wastewater and environment and written in English. The reference lists of all included articles were hand-searched for another relevant article. Finally, the eligible articles were independently screened and reviewed by each author.

\section{Data Quality}

The quality of the data was checked by each of the authors for the similarity of study design and inclusion and exclusion criteria.

\section{Summarizing, Analysis and Reporting}

A systematic review was performed according to the PRISMA protocol. A data abstraction tool was used to construct data from each article selected for review and presented in a table. A total of 35,999 articles were identified through database searching and hand searching. Twenty-seven (27) research articles were obtained in the initial literature search done in Ethiopia after removing the 5 duplicate articles; the first screening removed 9 articles through observing titles and abstracts. Finally, 13 full-text articles were assessed for eligibility and a total of seven research articles were qualified for inclusion in the review analysis (Figure 1). All research articles were summarized in the table clearly with the key information and findings (Tables 1 and 2). All seven included articles are used the same pathogens and antimicrobials resistance detection methods (culture plus disk diffusion methods and interpreted according to CLSI).

\section{Result}

\section{Overview of the Included Research}

\section{Studies}

Based on the selection criteria, a total of seven original research articles were included and all are conducted using a cross-sectional study design. Among the article, two 


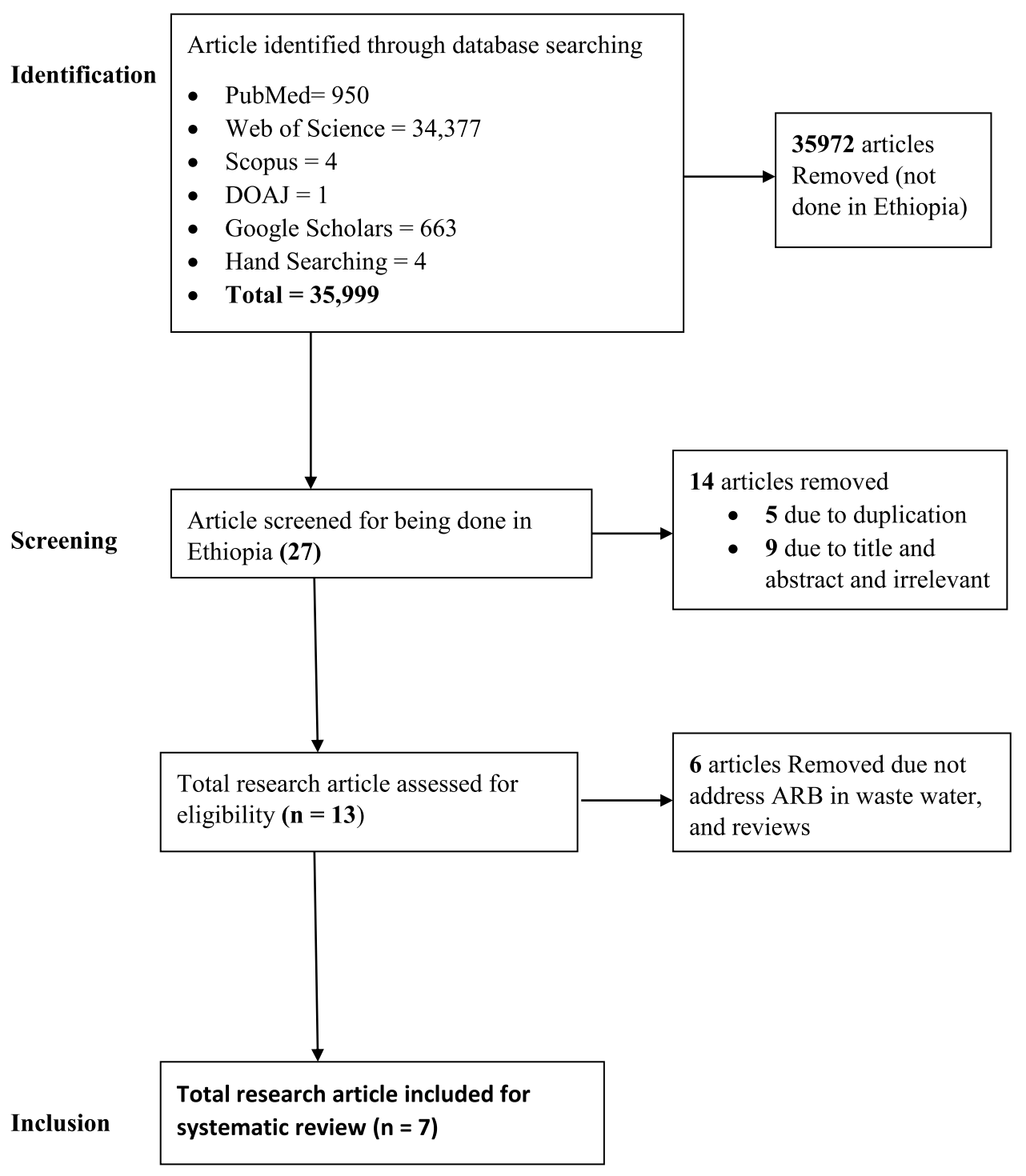

Figure I Flow chart of selections of studies that assessed ARB in wastewater released to the environment in Ethiopia.

were done in Southern, Ethiopia, ${ }^{10,11}$ two were done in Gondar, Northwest Ethiopia, ${ }^{12,13}$ two were done in Addis Ababa, Ethiopia ${ }^{1,15}$ and one was from Mekelle North Ethiopia. ${ }^{16}$ The included articles were assessed hospital wastewater from the inlet and outlet of oxidation pond, ${ }^{11,16}$ temporary septic tank, ${ }^{10,11}$ Superficial wastewater and different outlet from a different section of hospital, ${ }^{12}$ sewage polluted downstream revers, ${ }^{14,15}$ superficial wastewater from different nonhospital institutions, ${ }^{12}$ the surface of bed frames, bedside tables, door handles, floor sinks, chars and walls of different wards, hospital sewerage system, ${ }^{13}$ hospital sewerage system ${ }^{13,15}$ and Wastewater Treatment Plant (WWTP). ${ }^{15}$ Four of the included articles were assessed both gram-negative and gram-positive bacteria, ${ }^{10-12,16}$ the other research assessed gram negative-bacteria, ${ }^{14}$ Enterobacteriaceae ${ }^{15}$ and Extended Resistant Beta-lactam Antibiotics (ESBL) producing Enterobacteriaceae ${ }^{13}$ (Table 1).

\section{Bacterial Isolates}

All included studies used different sample sizes to meet their objective (40 composite samples, ${ }^{10} 24$ composite samples, ${ }^{11} 60$ grab samples, ${ }^{12} 384$ grab samples, ${ }^{13} 90$ grab samples, ${ }^{14} 24$ duplicate samples ${ }^{15}$ and 40 composite samples ${ }^{16}$ ). Some of the included studies obtained a large volume of indicator organisms from treated hospital wastewater. $^{10,11,16}$ All studies isolate a wide range of bacterial pathogens. The most frequently isolated bacteria were E. coli, Staphylococcal spp., and Klebsiella spp., respectively, from treated final wastewater, ${ }^{10}$ 
Table I Description of Relevant Studies Included in Systematic Review

\begin{tabular}{|c|c|c|c|c|c|c|c|}
\hline ID & Reference & $\begin{array}{l}\text { Study } \\
\text { Area }\end{array}$ & $\begin{array}{l}\text { Source of } \\
\text { Sample and } \\
\text { Year of } \\
\text { Sampling }\end{array}$ & Sampling Point & $\begin{array}{l}\text { Study } \\
\text { Objective }\end{array}$ & Key Findings & Recommendation \\
\hline I & $\begin{array}{l}\text { S. dires } \\
\text { et al } 2018^{10}\end{array}$ & $\begin{array}{l}\text { Hawassa } \\
\text { University, } \\
\text { Southern } \\
\text { Ethiopia }\end{array}$ & $\begin{array}{l}\text { Hospital } \\
\text { Wastewater } \\
(2017)\end{array}$ & $\begin{array}{l}\text { Inlet and Outlets of } \\
\text { temporary collection tank }\end{array}$ & $\begin{array}{l}\text { Effectiveness in } \\
\text { the removal of } \\
\text { ARB from } \\
\text { hospital } \\
\text { wastewater }\end{array}$ & $\begin{array}{l}\text { Indicator } \\
\text { organism, ARB } \\
\text { and MDR } \\
\text { bacteria in } \\
\text { treated } \\
\text { wastewater }\end{array}$ & $\begin{array}{l}\text { Constructed wetland } \\
\text { Could be promoted }\end{array}$ \\
\hline 2 & $\begin{array}{l}\text { Fekadu } \\
\text { et al } 2015^{11}\end{array}$ & $\begin{array}{l}\text { Yirgalem } \\
\text { and } \\
\text { Hawassa, } \\
\text { Southern } \\
\text { Ethiopia }\end{array}$ & $\begin{array}{l}\text { Hospital } \\
\text { wastewater } \\
\text { (Dec,2010 - } \\
\text { Feb, 2011) }\end{array}$ & $\begin{array}{l}\text { Inlet and Outlets of } \\
\text { Pretreated septic tank } \\
\text { (Yirgalem) Oxidation pond } \\
\text { system (Hawassa) }\end{array}$ & $\begin{array}{l}\text { Assessment of } \\
\text { antibiotic and } \\
\text { disinfectant } \\
\text { resistant bacteria }\end{array}$ & $\begin{array}{l}\text { Indicator } \\
\text { organism, } \\
\text { Pathogenic and } \\
\text { ARB bacteria in } \\
\text { the final } \\
\text { effluent of } \\
\text { wastewater }\end{array}$ & $\begin{array}{l}\text { Proper wastewater } \\
\text { treatment before } \\
\text { released to receiving } \\
\text { environment }\end{array}$ \\
\hline 3 & $\begin{array}{l}\text { Moges et al } \\
2014^{12}\end{array}$ & $\begin{array}{l}\text { Gondar, } \\
\text { Northwest } \\
\text { Ethiopia }\end{array}$ & $\begin{array}{l}\text { Hospital } \\
\text { wastewater } \\
\text { and } \\
\text { Nonhospital } \\
\text { Environment } \\
(2012)\end{array}$ & $\begin{array}{l}\text { Superficial wastewater and } \\
\text { a different outlet from } \\
\text { different section of the } \\
\text { hospital and Superficial } \\
\text { wastewater from different } \\
\text { nonhospital institutions }\end{array}$ & $\begin{array}{l}\text { Isolate and } \\
\text { characterize } \\
\text { public health } \\
\text { important } \\
\text { bacteria }\end{array}$ & $\begin{array}{l}\text { MDR bacteria } \\
\text { in wastewater } \\
\text { and high } \\
\text { prevalence in } \\
\text { hospital } \\
\text { wastewater }\end{array}$ & $\begin{array}{l}\text { Proper wastewater } \\
\text { treatment plant } \\
\text { should be established } \\
\text { and improved } \\
\text { sanitary measure } \\
\text { should be practice. }\end{array}$ \\
\hline 4 & $\begin{array}{l}\text { Engda et al } \\
2018^{13}\end{array}$ & $\begin{array}{l}\text { Gondar, } \\
\text { Northwest } \\
\text { Ethiopia }\end{array}$ & $\begin{array}{l}\text { Hospital } \\
\text { Environment } \\
\text { and } \\
\text { Wastewater } \\
(2014)\end{array}$ & $\begin{array}{l}\text { Surface of bed frames, } \\
\text { bedside tables, door handle, } \\
\text { floors, sinks, waiting chairs } \\
\text { and walls of different wards } \\
\text { and hospital sewerage system }\end{array}$ & $\begin{array}{l}\text { Magnitude, } \\
\text { distribution, and } \\
\text { antimicrobial } \\
\text { susceptibility of } \\
\text { ESBL producing } \\
\text { Enterobacteriaceae }\end{array}$ & $\begin{array}{l}\text { High } \\
\text { prevalence of } \\
\text { MDR bacteria } \\
\text { to the } \\
\text { commonly used } \\
\text { Antibiotics }\end{array}$ & $\begin{array}{l}\text { Hospital should } \\
\text { install proper hygiene } \\
\text { and rational use of } \\
\text { antimicrobials. }\end{array}$ \\
\hline 5 & $\begin{array}{l}\text { Belachew } \\
\text { et al } 2018^{14}\end{array}$ & $\begin{array}{l}\text { Addis } \\
\text { Ababa, } \\
\text { Ethiopia }\end{array}$ & $\begin{array}{l}\text { Sewage } \\
\text { Polluted } \\
\text { Urban } \\
\text { Rivers,2017 }\end{array}$ & Downstream of Rivers & $\begin{array}{l}\text { Determine the } \\
\text { level of drug } \\
\text { resistance of } \\
\text { gram-negative } \\
\text { bacteria }\end{array}$ & $\begin{array}{l}\text { Medically } \\
\text { important } \\
\text { gram-negative } \\
\text { bacteria with } \\
\text { a high degree of } \\
\text { MDR }\end{array}$ & $\begin{array}{l}\text { Not stated or No } \\
\text { recommendations }\end{array}$ \\
\hline 6 & $\begin{array}{l}\text { Tesfaye } \\
\text { et al } 2019^{15}\end{array}$ & $\begin{array}{l}\text { Addis } \\
\text { Ababa, } \\
\text { Ethiopia }\end{array}$ & $\begin{array}{l}\text { Health } \\
\text { facilities, } \\
\text { abattoir, } \\
\text { Rivers and } \\
\text { WWTP.2017 }\end{array}$ & $\begin{array}{l}\text { Hospital sewerage system, } \\
\text { Downstream revers and } \\
\text { WWTP }\end{array}$ & $\begin{array}{l}\text { Antimicrobial } \\
\text { susceptibility of } \\
\text { Enterobacteriaceae }\end{array}$ & $\begin{array}{l}\text { ARB and MDR } \\
\text { bacteria in } \\
\text { Hospital } \\
\text { wastewater, } \\
\text { Downstream } \\
\text { revers and } \\
\text { WWTP }\end{array}$ & $\begin{array}{l}\text { Hospitals and } \\
\text { abattoir } \\
\text { Wastewater should } \\
\text { be treated. Further } \\
\text { studies should be } \\
\text { conducted. }\end{array}$ \\
\hline 7 & $\begin{array}{l}\text { T. Asfaw } \\
\text { et al } 2017^{16}\end{array}$ & $\begin{array}{l}\text { Mekelle, } \\
\text { North } \\
\text { Ethiopia }\end{array}$ & $\begin{array}{l}\text { Hospital } \\
\text { Wastewater } \\
(2015)\end{array}$ & $\begin{array}{l}\text { Inlet and Outlets of } \\
\text { Oxidation pond system }\end{array}$ & $\begin{array}{l}\text { Prevalence and } \\
\text { drug resistance of } \\
\text { bacterial } \\
\text { pathogen }\end{array}$ & $\begin{array}{l}\text { Indicator } \\
\text { organism, ARB } \\
\text { and MDR } \\
\text { bacteria in } \\
\text { treated } \\
\text { wastewater }\end{array}$ & $\begin{array}{l}\text { Liquid waste } \\
\text { treatment system } \\
\text { (Chlorination) should } \\
\text { be developed }\end{array}$ \\
\hline
\end{tabular}


Table 2 Type of Bacteria Isolated, Antibiotic Used and Drug Resistance Patterns for Studies Included in Systematic Review

\begin{tabular}{|c|c|c|c|c|}
\hline ID & Reference & Type of Bacteria Isolated & Antibiotic Tested Against Isolates & Drug Resistance Pattern \\
\hline 1 & $\begin{array}{l}\text { S. Dires } \\
\text { et al } 2018^{10}\end{array}$ & $\begin{array}{l}\text { E. coli, Shigella spp., Pseudomonas spp., } \\
\text { Staphylococcus spp., Klebsiella spp., } \\
\text { Salmonella spp., and Citrobacter spp., }\end{array}$ & $\begin{array}{l}\text { Ciprofloxacin, Ceftriaxone, } \\
\text { Ceftazidime, Cotrimoxazole, } \\
\text { Erythromycin, Nalidixic Acid, } \\
\text { Doxycycline, Amoxicillin-clavulanic, } \\
\text { Cefoxitin, Gentamicin and } \\
\text { Chloramphenicol }\end{array}$ & $\begin{array}{l}\text { The overall MDR prevalence in the final } \\
\text { wastewater was } 34.2 \% \text {, where } E \text {. coli } \\
\text { and Klebsiella spp. were dominated with } \\
47 \% \text { and } 46.1 \% \text { respectively }\end{array}$ \\
\hline 2 & $\begin{array}{l}\text { Fekadu } \\
\text { et al } 2015^{\prime \prime}\end{array}$ & $\begin{array}{l}\text { Staphylococcus spp., Klebsiella spp., E. coli, } \\
\text { Bacillus spp., Proteus spp., Enterococci } \\
\text { spp., Salmonella spp., Shigella spp., } \\
\text { Citrobacter spp. }\end{array}$ & $\begin{array}{l}\text { Gentamycin, Erythromycin, Penicillin, } \\
\text { Amoxicillin, Ampicillin, Ciprofloxacin, } \\
\text { Erythromycin, Tetracycline, Ceftriaxone } \\
\text { and }\end{array}$ & $\begin{array}{l}\text { E. coli, Salmonella and S. aureus were } \\
\text { found to be MDR pathogens from final } \\
\text { wastewater effluents }\end{array}$ \\
\hline 3 & $\begin{array}{l}\text { Moges et al } \\
2014^{12}\end{array}$ & $\begin{array}{l}\text { E. coli, Klebsiella spp., Shigella spp., } \\
\text { Pseudomonas spp., Staphylococcus spp., } \\
\text { Enterococci, Citrobacter spp., Enterobacter } \\
\text { spp., Providencia, Morganella spp., Proteus } \\
\text { spp., Serratia and Edwardsiella spp }\end{array}$ & $\begin{array}{l}\text { Ampicillin, Chloramphenicol, } \\
\text { Ciprofloxacin, Clindamycin, } \\
\text { Erythromycin, Gentamicin, Methicillin, } \\
\text { Vancomycin, Streptomycin, } \\
\text { Trimethoprim-Sulfamethoxazole, } \\
\text { Tetracycline, Nalidixic Acid, } \\
\text { Cephalothin, Cefotaxime, Kanamycin }\end{array}$ & $\begin{array}{l}\text { The overall MDR prevalence was } 69.9 \% \\
\text { where } 54.2 \% \text { in the non-hospital } \\
\text { environment and } 81.5 \% \text { from the } \\
\text { hospital environment. Enterobacter spp., } \\
\text { Klebsiella spp. and Pseudomonas were } \\
\text { most MDR gram-negative bacteria while } \\
\text { S. aureus was resistant to all antibiotics } \\
\text { except Vancomycin }\end{array}$ \\
\hline 4 & $\begin{array}{l}\text { Engda et al } \\
2018^{13}\end{array}$ & $\begin{array}{l}\text { E. coli, K. pneumoniae } \\
\text { K. ozenae, P. Mirabilis } \\
\text { E. cloacae, E. aerogens, } \\
\text { Citrobacter spp., and P. stuartii }\end{array}$ & $\begin{array}{l}\text { Beta-lactam and non-beta-lactam } \\
\text { antimicrobials }\end{array}$ & $\begin{array}{l}56 \% \text { of ESBL producing } \\
\text { Enterobacteriaceae were MDR for non- } \\
\text { beta-lactam antibiotics. All ESBL } \\
\text { producing Enterobacteriaceaewere found } \\
\text { to be } 100 \% \text { resistant to cefpirome, } \\
\text { cefpodoxime, ceftazidime, } \\
\text { Ceftriaxone and amoxicillin with } \\
\text { clavulanic acid. }\end{array}$ \\
\hline 5 & $\begin{array}{l}\text { Belachew } \\
\text { et al } 2018^{14}\end{array}$ & $\begin{array}{l}\text { E. coli, K. pneumoniae } \\
\text { K. oxytoca, P. alcalifaciens, C. freundii, } \\
\text { P. rettgeri, and M. morganii }\end{array}$ & $\begin{array}{l}\text { Ampicillin, Cefazolin, Amoxicillin/ } \\
\text { Clavulanic acid, Piperacillin/Tazobactam, } \\
\text { Cephalothin, Cefuroxime, Cefuroxime, } \\
\text { Cefoxitin, Cefpodoxime, Ceftazidime, } \\
\text { Ceftriaxone, Cefepime, Gentamicin, } \\
\text { Tobramycin, Ciprofloxacin, } \\
\text { Levofloxacin, Tetracycline, } \\
\text { Nitrofurantoin, Trimethoprim/ } \\
\text { sulfamethoxazole }\end{array}$ & $\begin{array}{l}\text { The overall MDR prevalence was } 64 \% \text {. } \\
\text { P. rettgeri was } 100 \% \text { MDR followed by } \\
\text { P. alcalifaciens ( } 90 \%) \text {, E. coli }(78 \%) \text { and } \\
\text { C. freundii }(60 \%)\end{array}$ \\
\hline 6 & $\begin{array}{l}\text { Tesfaye } \\
\text { et al } 2019^{15}\end{array}$ & $\begin{array}{l}\text { E. coli, Salmonella spp., Klebsiella spp., } \\
\text { Klebsiella oxytoca, Enterobacter cloacae, } \\
\text { and Enterobacter aerogens }\end{array}$ & $\begin{array}{l}\text { Amoxicillin + Clavulanic acid, } \\
\text { Ciprofloxacin, Gentamicin, } \\
\text { Sulfamethoxazole + Trimethoprim, } \\
\text { Trimethoprim, Tetracycline, Ampicillin, } \\
\text { Cephalothin, Cefoxitin, Sulfisoxazole, }\end{array}$ & $\begin{array}{l}23 \% \text { isolates produce ESBL. The isolates } \\
\text { include Klebsiellapneumoniae, E. coli and } \\
\text { Enterobacter cloacae }\end{array}$ \\
\hline 7 & $\begin{array}{l}\text { T. Asfaw } \\
\text { et al } 2017^{16}\end{array}$ & $\begin{array}{l}\text { S. aureus, Coagulase-negative } \\
\text { staphylococci, Klebsiella spp., } \\
\text { P. aeruginosa, E. coli, Salmonella spp., } \\
\text { Shigella spp., Citrobacter spp., } \\
\text { Enterobacter spp., Serratia spp. and } \\
\text { Proteus spp. }\end{array}$ & $\begin{array}{l}\text { Erythromycin, Gentamycin, Amikacin, } \\
\text { Amoxicillin-Clavulanic acid, } \\
\text { Ceftriaxone, Ciprofloxacin, } \\
\text { Tetracycline, Cotrimoxazole, Ampicillin, } \\
\text { Penicillin, Chloramphenicol, } \\
\text { Doxycycline and Cefoxitin }\end{array}$ & $\begin{array}{l}\text { Overall MDR prevalence from final } \\
\text { effluents was } 84 \% \text {. Among isolates, } \\
28.6 \% \text { were resistant to for six and } \\
\text { more antibiotics. One isolates of } \\
\text { Citrobacter spp. was resistant for } 9 \\
\text { antibiotics. }\end{array}$ \\
\hline
\end{tabular}


Staphylococcus aureus, E. coli, Salmonella spp. and Shigella spp. were also frequently isolated from final effluent, ${ }^{11}$ Klebsiella spp., Pseudomonas spp., E. coli, Citrobacter spp. and $S$. aureus were detected from the hospital and the non-hospital environment from a study done in Gondar, Northwest Ethiopia, ${ }^{12}$ from ESBL producing Enterobacteriaceae, K. pneumoniae, E. coli, and Proteus mirabilis were predominantly isolated in Addis Ababa $^{13}$ from gram-negative bacteria E. coli, $K$. pneumoniae, and K. oxytoca were predominant isolates from study done in Addis Ababa, ${ }^{14}$ from a study done by Tesfaye et al E. coli, Salmonella spp., $K$. pneumoniae, and E. aerogens were the dominant isolates, ${ }^{15}$ finally, in the study done in Mekelle, North Ethiopia from treated hospital wastewater, Klebsiella spp., P. aeruginosa and $S$. aureus were frequently detected bacteria (Table 2).

\section{Antibiotic Resistance Patterns of Bacterial Isolates}

Among isolates, from a study done in Southern Ethiopia, the frequency of resistance from treated wastewater is high for ampicillin, cotrimoxazole, doxycycline, and chloramphenicol ${ }^{10}$ and a higher resistance was obtained for Pseudomonas spp., Salmonella spp., Klebsiella spp., E. coli, and Shigella spp. ${ }^{10}$ Similarly, E. coli, Salmonella spp., Shigella spp. and S.aureus were resistant for different antibiotics tested from Hawassa and Yirgalem hospital final effluents. ${ }^{11}$ From a study done in Gondar, Ethiopia, most isolates of grampositive and gram-negative bacteria were resistant for many antibiotics tested ${ }^{12}$, and at the same time another study revealed that all ESBL producing Enterobacteriaceae showed $100 \%$ resistance to betalactam drugs and $19.3 \%$ to $70.18 \%$ resistance for nonbeta-lactam drugs. ${ }^{13}$ A study done in Addis Ababa from sewage polluted urban revers showed a high level of resistance by gram-negative bacteria for different antibiotics tested. ${ }^{14,15}$ A study was done in Mekelle; North Ethiopia also showed $100 \%$ penicillin-resistant isolates of $S$. aureus and Coagulase-negative staphylococci, and $100 \%$ ampicillin-resistant E. coli, Klebsiella spp. and Citrobacter spp. ${ }^{16}$ Penicillin was $100 \%$ resistant followed by ampicillin $83 \%$ and Ceftriaxone $59 \%$ for isolates from treated hospital wastewater in Mekelle, north Ethiopia. $^{16}$

\section{Multidrug Resistance (MDR) Patterns of Isolates}

Among isolates from treated and final effluents in Southern Ethiopia, the overall MDR prevalence was $34.2 \%{ }^{10}$ and pathogenic MDR bacteria also detected. ${ }^{12}$ A study done in Gondar showed the overall prevalence of MDR (two or more drugs) was $69.9 \%$ where $81.5 \%$ in the hospital environment and $54.2 \%$ in the nonhospital environment. ${ }^{12}$ According to this study, MDR was common for both gram-positive and gram-negative isolates. ${ }^{12}$ Another study done from Gondar also showed a high burden of MDR bacteria. ${ }^{13}$ A study was done in Addis Ababa, Ethiopia also showed medically important gramnegative bacteria with a high degree of MDR. ${ }^{14,15}$ A study was done in Mekelle; North Ethiopia also showed a high degree of MDR bacteria isolates with a total prevalence of $84 \%{ }^{16}$

\section{Discussion}

This review summarized the results from seven studies investigating pathogenic ARB for multiple antibiotics from wastewater in Ethiopia. Increasing knowledge on the dissemination of pathogenic ARB through surveillance and research was a key strategic plan for WHO. ${ }^{17}$ Therefore, this summarized study highlighted the role of wastewater as a major source of pathogenic bacteria with MDR to the environment which is a global problem with a serious implication on public health.

From this review, three studies obtained indicator organisms from hospital wastewater which exceed WHO for restricted and unrestricted irrigation, ${ }^{18,19}$ Health Protection Agency, ${ }^{20}$ Environmental Protection Agency ${ }^{21}$ and Food and Agriculture Organization ${ }^{22}$ standard permissible and tolerable level which indicates that microbial contamination and fecal pollution of the environment. ${ }^{10,11,16}$ The number of coliforms released from hospital mostly depends on the number of patients served, hospital capacity, and the type of case-managed. ${ }^{23}$ During the diagnosis and treatment of disease, the hospital releases large amounts of pathogenic bacteria. ${ }^{23}$ At the same time hospital could be a storm house of ARB due to the large use of antibiotics to treat bacterial infections. ${ }^{24}$

Almost all studies showed the presence of pathogenic bacterial isolates such as klebsiella spp., E. coli, P. aeruginosa, S. aureus, and Salmonella spp. in the final wastewater and environment. Those isolates are among the lists of WHO that identified bacterial species and their 
complementary antibiotic-resistance profile that pose the greatest threat to human health. ${ }^{25}$ The bacterium in wastewater is a public health problem with risk factors in all parts of the world. Waterborne pathogens can occur in all types of water sources particularly in improperly treated wastewater. Therefore, if wastewater is improperly treated large amounts of infectious agents and ARB are shed into communities causing waterborne disease. ${ }^{26}$

All studies reported MDR bacteria in the wastewater released to the environment. The use of antibiotics and the dissemination of ARB in the clinical setting are studied well across the world but overlooked in the environment. $^{27-29}$ This is one of the challenges to attain one health approach that aims to achieve an optimum health approach for people, animals, and the environment. $^{30}$ Currently in Ethiopia, the use of natural compost having human and animal feces as fertilizer is encouraged. This can be one way for the spread of ARB within the environment since water and soil contaminated by slurry, fermentation residue, sewage sludge, municipal wastewater, particularly wastewater with indirect entry from healthcare facilities, are generally contaminated directly with ARB through excretions from people and animals. $^{31}$

Human and animal treatments are the main routes where antibiotics are introduced to the environment. Antibiotics are excreted through feces and urine of patients and reached to the environment and act as a selective pressure on naturally susceptible microflora to develop ARB and ARGs. ${ }^{32}$ Moreover, if the resistant genes are transmissible and these bacteria reach community bacterial strains, it causes the wide dissemination of resistance gene and resistance bacteria in the receiving environment. ${ }^{33}$ Especially, hospital bacteria could increase the number of resistant bacteria in the recipient sewers due to large concentrations of antibiotics and biocide. ${ }^{5,6}$ Infections caused by ARB are usually difficult to treat, prolong hospitalization, and increase the cost of treatment. This can be even worse in the developing countries since more than half of the population does not have access to proper sanitation and more than $80 \%$ of the wastewater generated is directly discharged into the open field and surface waterbodies. ${ }^{34}$ In Ethiopia, the sanitation facility coverage is very low, and a large number of populations use open defecations. ${ }^{35}$ The habit of open field disposal of wastewater is one of the main causes of soil and water contaminations and the cause of many communicable diseases. ${ }^{36}$
Multiple drug resistance bacteria undergo wideranging genetic exchange in the environment where opportunistic (commonly found in free-living communities) may become resistant upon acquiring resistance mechanisms. The growing distribution of ARB among environmental bacteria has led to consider ARB as emerging pollutants ${ }^{37-39}$ and have unique property compared to contaminants due to their ability to amplify, spread, and persisting in the environment for a long period. ${ }^{39}$ The presence of MDR in the environment is a major public health threat since it can infect humans and animals through contaminated food and drinking water or directly from the environment. ${ }^{40}$ Antibiotic resistance presents in bacteria which are not primary pathogens also, a threat to public health due to possibilities of transmittance of resistance to other microorganisms. ${ }^{41}$ Therefore, the reduction of selective pressure by regulating the use of antibiotics is a key step to reduce the dissemination of resistance in wastewater in order to not favor resistant strains. $^{42}$

\section{Conclusion and Recommendations}

Large numbers of bacteria were isolated from wastewater. This is an indication of the possible presence of pathogenic organisms in the receiving environment. The absence of wastewater treatment and low habit of disinfection before releasing into the sewerage system contribute to the dissemination of MDR bacteria to the environment possibly waterbodies for example, lakes, rivers, posing risk to public health, animals and environment. Especially in Ethiopia were those waterbodies used as public consumption the problem even become worse. This study showed wastewater isolates with significantly higher antibiotic resistance rates. Therefore, wastewater should be treated by an appropriate wastewater treatment system before released into the environment. Moreover, there should be regular assessments and evaluations of the final quality of the wastewater before discharging into the receiving environment. Large-scale microbiological, epidemiological, and social science studies should be conducted across the one-health spectrum in order to decrease the gaps of knowledge about ARB and to increase the wastewater management system.

\section{Limitation of the Study}

This study is not assessed possible occupational health risks of wastewater and management practices. The included research articles were not designed at molecular 
levels so that this review did not assess the presence of resistance genes and other associated factors.

\section{Data Sharing Statement}

Not applicable to this article as no datasets were generated.

\section{Author Contributions}

All authors made a significant contribution to the work reported, whether that is in the conception, study design, execution, acquisition of data, analysis and interpretation, or in all these areas; took part in drafting, revising or critically reviewing the article; gave final approval of the version to be published; have agreed on the journal to which the article has been submitted; and agree to be accountable for all aspects of the work.

\section{Funding}

There is no funding to report.

\section{Disclosure}

The authors declare that they have no potential conflicts of interest for this work.

\section{References}

1. World Bank. Pulling together to beat superbugs: knowledge and implementation gaps in addressing antimicrobial resistance. Washington, DC: World Bank; 2019.

2. World Health Organization. WHO report on surveillance of antibiotic consumption 2016-2018 early implementation. Available from: https://www.who.int/medicines/areas/rational_use/oms-amr-amcreport-2016-2018/en/. Accessed June 212020.

3. Holmes AH, Moore LS, Sundsfjord A, et al. Understanding the mechanisms and drivers of antimicrobial resistance. Lancet. 2016;387:176-187. doi:10.1016/S0140-6736(15)00473-0

4. Review on Antimicrobial Resistance. Tackling drug-resistant infections globally: final report and recommendations. Available from: https://amrreview.org/sites/default/files/160525_Final\%20paper_with \%20cover.pdf. Accessed June 21, 2020.

5. Kummerer K. Resistance in the environment. $J$ Antimicrob Chemother. 2004;54(2):311-320. doi:10.1093/jac/dkh325

6. Zhang XX, Zhang T. Antibiotic resistance genes in water environment. Appl Microbiol Biotechnol. 2009;82(3):397-414. doi:10.1007/s00253-008-1829-z

7. Omar SM, Masudul Azad CAM, Nayeem UK. Isolation of cefixime resistant Salmonella from hospitals waste and profiling multi-drug resistance pattern of the selected isolates. Int Res J Biol Sci. 2014;3(9):86-92.

8. World Health Organization: Public Health and Environment. Overview of wastes from health care activities. Osaka, Japan: UNEP IETC; 2012.

9. Asfaw T. Review on hospital wastewater as a source of emerging drug resistance pathogens. J Res Environ Sci Toxicol. 2018;7 (2):47-52. doi:10.14303/jrest.2018.020

10. Dires S, Tarekegn Birhanu T, AmbelU A, SahilU G. Antibiotic resistant bacteria removal of subsurface flow constructed wetlands from hospital wastewater. J Environ Chem Eng. 2018;6:4265-4272. doi:10.1016/j.jece.2018.06.034
11. Fekadu S, Merid Y, Beyene H, Teshome W, Selassie S. Assessment of antibiotic and disinfectant resistant bacteria in hospital wastewater, South Ethiopia. J Infect Dev Ctries. 2015;9:149-156. doi:10.3855/ jidc. 4808

12. Moges F, Endris M, Belyhun Y, Worku W. Isolation and characterization of multiple drug resistance bacterial pathogens from waste water in hospital and non-hospital environments, northwest Ethiopia. BMC Res Notes. 2014;7:215. doi:10.1186/1756-0500-7-215

13. Engda T, Moges F, Gelaw A, Eshete S, Mekonnen F. Prevalence and antimicrobial susceptibility patterns of extended spectrum beta-lactamase producing Enterobacteriaceae in the University of Gondar Referral Hospital environments, northwest Ethiopia. BMC Res Notes. 2018;11:335. doi:10.1186/s13104-018-3443-1

14. Belachew T, Mihret A, Legesse T, Million Y, Desta K. High level of drug resistance by gram-negative bacteria from selected sewage polluted urban rivers in Addis Ababa, Ethiopia. BMC Res Notes. 2018;11:524. doi:10.1186/s13104-018-3622-0

15. Tesfaye H, Alemayehu H, Desta AF, Eguale T. Antimicrobial susceptibility profile of selected Enterobacteriaceae in wastewater samples from health facilities, abattoir, downstream rivers and a WWTP in Addis Ababa, Ethiopia. Antimicrob Resist Infect Control. 2019;8:134. doi:10.1186/s13756-019-0588-1

16. Asfaw T, Negash L, Kahsay A, Weldu Y. Antibiotic resistant bacteria from treated and untreated Hospital wastewater at ayder referral Hospital, mekelle, North Ethiopia. Adv Microbiol. 2017;7(12): 871-886.

17. World Health Organization. Global action plan on antimicrobial resistance. Available from: https://www.who.int/antimicrobialresistance/publications/global-action-plan/en/. Accessed June 21, 2020.

18. World Health Organization (WHO). Guidelines for the safe use of wastewater, excreta and greywater, wastewater use in agriculture. World Health Organization; 2006.

19. Ursula BJ, Mara DD, Peasey A, Ruiz-Palacios G, Stott R. Guidelines for the microbiological quality of treated wastewater used in agriculture. Bull World Health Organ. 2000;78:1104-1116.

20. Health Protection Agency (HPA). The microbiological examination of water samples. National Standard Method QSOP 57; 2005. Available from: http://www.hpa-standardmethods.org.uk/pdf_sops.asp.

21. Environmental Protection Agency (EPA). US environment protection agency, safe drinking water act amendments. 2002. Available from: http://www.epa.Gov/safewater/mcl.Html. Accessed December 4, 2020.

22. Food and Agriculture Organization (FAO) (Regional Office for the Near East) User's manual for irrigation with treated wastewater. 2003:60.

23. Akin BS. Contaminant properties of hospital clinical laboratory wastewater: a physiochemical and microbiological assessment. J Environ Prot (Irvine, Calif). 2016;7(7):635-642. doi:10.4236/jep.2016.75057

24. Kümmerer K. Drugs in the environment: emission of drugs, diagnostic aids and disinfectants into wastewater by hospitals in relation to other sources - a review. Chemosphere. 2001;45(6-7):957-969. doi:10.1016/S0045-6535(01)00144-8

25. World Health Organization. Report on global priority list of antibiotic-resistant bacteria to guide research, discovery, and development of new antibiotics. Available from: https://www.who.int/med icines/publications/global-priority-list-antibiotic-resistant-bacteria/en/ . Accessed June 21, 2020.

26. Khan M, Ashfaq A, Pijush S, Majharul IM, Kant OR, Chandra BG. Screening of antibiotic resistant gram-negative bacteria and plasmid profiling of multi-drug resistant isolates present in sewage associated with health care centers. Int $J$ Med Res Health Sci. 2013;2 (4):923-930. doi:10.5958/j.2319-5886.2.4.148

27. Jorgensen SE, Halling-Sorensen B. Drugs in the environment. Chemosphere. 2000;40:691-699. doi:10.1016/S0045-6535(99)004 $38-5$ 
28. Kim S, Aga DS. Potential ecological and human health impacts of antibiotics and antibiotic-resistant bacteria from wastewater treatment plants. J Toxicol Environ Health B Crit Rev. 2007;10:559-573. doi:10.1080/15287390600975137

29. Sahlstrom L, Aspan A, Bagge E, Danielsson-Tham ML, Albihn A. Bacterial pathogen incidences in sludge from Swedish sewage treatment plants. Water Res. 2004;38:1989-1994. doi:10.1016/j.watres.20 04.01.031

30. Rousham EK, Unicomb L, Islam MA. Human, animal and environmental contributors to antibiotic resistance in low-resource settings: integrating behavioural, epidemiological and One Health approaches. Proc Royal Soc B Biol Sci. 2018;285:20180332. doi:10.1098/rspb.20 18.0332

31. Haas CN, Hutzler NJ. Wastewater disinfection and infectious disease risks. Crit Rev Environ Control. 1986;17(1):1-20. doi:10.1080/ 10643388609388327

32. Asfaw T. Review on hospital wastewater as a source of emerging drug resistance pathogens. J Res Environ Sci Toxicol. 2018;7 (2):47-52. doi:10.14303/jrest.2018.020

33. Allen HK, Donato J, Wang HH, et al. Call of the wild: antibiotic resistance genes in natural environments. Nat Rev Microbiol. 2010;8 (4):251-259. doi:10.1038/nrmicro2312

34. UN HABITAT. Sick water? The central role of wastewater management in sustainable development. Accessed June 21, 2020. Available from: www.unhabitat.org.
35. Mengesha A, Mamo W, Tesfaye T. Sanitary survey in Gondar Town. Ethiop Med J. 2004;18(1):39-43.

36. Mekonnen FH. Liquid waste management: the case of Bahir Dar, Ethiopia. Ethiop J Health Dev. 2012;26(1):49-53.

37. Wright GD. Antibiotic resistance in the environment: a link to the clinic? Curr Opin Microbiol. 2010;13(5):589-594. doi:10.1016/j. mib.2010.08.005

38. Kummerer K. Antibiotics in the aquatic environment. A review- part I. Chemosphere. 2009;75(4):417-434. doi:10.1016/j.chemosphere.20 08.11.086

39. Pruden A, Pei R, Storteboom H, Carlson KH. Antibiotic resistance genes as emerging contaminants: studies in Northern Colorado Environ Sci Technol. 2006;40(23):7745-7750. doi:10.1021/es0604131

40. Al-Bahry SN, Mahmoud IY, Paulson JR, Al-Musharafi SK. Survival and growth of antibiotic resistant bacteria in treated wastewater and water distribution system and their implication inhuman health: a review. Int Arab J Antimicrob Agent. 2014;4(4):1.

41. Van der Kooij D, Van Lieverloo JHM, Schellart J, Hiemstra P. Maintaining quality without a disinfectant residual. $J$ Am Water Works Assoc. 1999;91:55-64. doi:10.1002/j.1551-8833.1999.tb085 68.x

42. Bush K, Courvalin P, Dantas G, et al. Tackling antibiotic resistance. Nat Rev Microbiol. 2011;9(12):894-896. doi:10.1038/nrmicro2693
Risk Management and Healthcare Policy

\section{Publish your work in this journal}

Risk Management and Healthcare Policy is an international, peerreviewed, open access journal focusing on all aspects of public health, policy, and preventative measures to promote good health and improve morbidity and mortality in the population. The journal welcomes submitted papers covering original research, basic science, clinical \& epidemiological studies, reviews and evaluations,

\section{Dovepress}

guidelines, expert opinion and commentary, case reports and extended reports. The manuscript management system is completely online and includes a very quick and fair peer-review system, which is all easy to use. Visit http://www.dovepress.com/testimonials.php to read real quotes from published authors. 